\title{
Problems of Older People and HIV and AIDS Scourge in Sub-Saharan Africa With Reference to Kenya
}

\author{
Michael Ang'anyo Onyango ${ }^{1}$, Solomon Leiro Letangule ${ }^{2}$ \\ ${ }^{1,2}$ Kenya School of Government, P.O. Box 91, Kabarnet, Kenya
}

\begin{abstract}
This paper examines the twin problem of older people and the HIV and AIDS scourge in Sub-Saharan Africa with reference to Kenya, particularly in the rural areas. Specifically, the paper assesses the direct and indirect effects of HIV and AIDS on the older people, and suggests policy and strategic measures that could be undertaken to empower older people to effectively respond to the HIV and AIDS scourge, in addition to their own problems of ageing. The central argument is that older people in Sub-Saharan Africa are increasingly being infected and affected by the HIV and AIDS scourge, and in some cases, forced to care for their adult HIV and AIDS sick children; and ultimately to their orphaned and vulnerable grandchildren. At the same time, the problems of the older people, who traditionally were largely supported by their working adult children, are worsening; as the adult children no longer effectively give support to their ageing parents, usually living in the rural areas. There is need for Sub-Saharan African Governments, the NonGovernment Organizations (NGOs), the Charity Organizations, and other relevant institutions operating in the region, to include and support the older generation in programmes to fight HIV and AIDS scourge and empower the older people to effectively care for their grandchildren orphaned by AIDS scourge as they address their own ageing problems. The paper is based on a review of various reports on old age problems and HIV and AIDS scourge, and its impacts on older people.

Keywords: older people problems, ageing, HIV and AIDS scourge, Sub-Saharan Africa, Kenya
\end{abstract}

\section{INTRODUCTION}

Older people, defined in this paper as "those aged 60 years and above ${ }^{1}$, or the ageing, defined as the life-long process of progressive changes in biological, psychological and social structures of a person due to advancement in age ${ }^{2 "}$, pose serious concerns to socio-economic developments, worldwide, as mortality and fertility rates fall and longevity increases, especially in developing countries, but particularly in Sub-Saharan Africa (SSA) ${ }^{3}$ where most countries are still poor; and yet, their populations are growing older before the countries become rich (DFID 1999; Disney 1996; HAI 2001; UN 19974; UN 2010; Velkoff and Kowal 2007). Statistics indicate that in 2006, 64\% of the worldwide population aged 60 and above lived in developing countries, today, it is approximately $70 \%$; and this proportion is projected to increase to nearly $73 \%$ by $2030^{5}$ and to about $78 \%$ in 2050 (UN 2010; Velkoff and Kowal 2007). In most Sub-Saharan African countries, Kenya included, although the older people currently account for a small proportion of the population, only about 4\%; the absolute number of older people is growing more rapidly than in the developed world (See Figure 1). For example, in 2006, 35 million people were aged 60 and above in Sub-Saharan Africa, this number is about 40 million today and is projected to increase to over 69 million by 2030; and to nearly 140 million in 2050 (UN 2010; Velkoff and Kowal 2007) (See Table 1). 
Problems of Older People and HIV and AIDS Scourge in Sub-Saharan Africa With Reference to Kenya

Figure 1. Average Annual Growth Rate of the Population Aged 60 and over in Sub-Saharan Africa and More Developed Countries 2005 to 2050

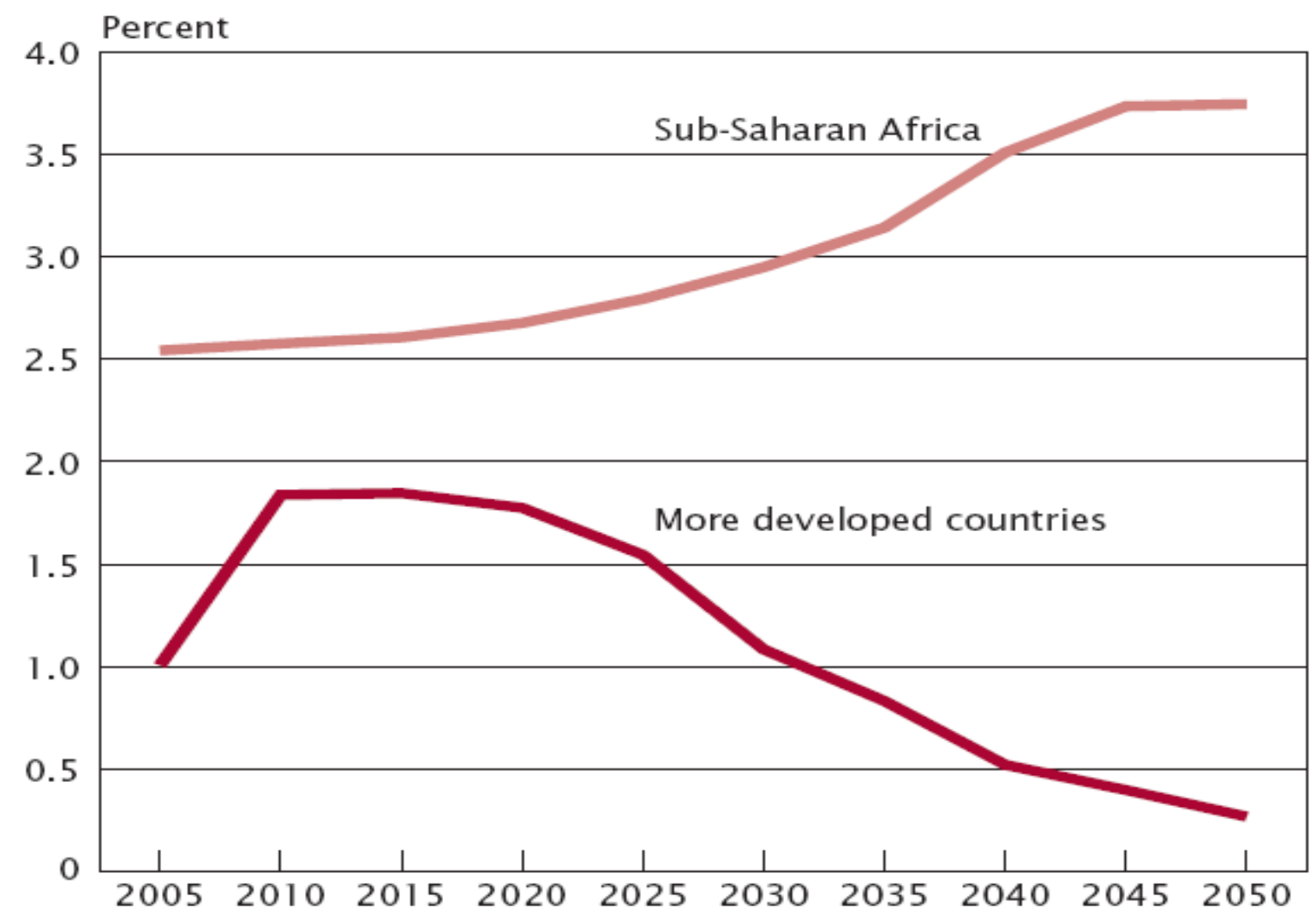

Source: Velkoff and Kowal 2007 from the U.S. Census Bureau, International Data Base, 2006

In the coming decades, governments and policy-makers in Sub-Saharan African countries such as Kenya will increasingly have to address issues relating to the process of population ageing ${ }^{6}$. As people advance in age, they change, become physically weaker, dependent and more susceptible to illnesses ${ }^{7}$. The rapid growth of the older population presents various challenges to the countries' economies, particularly to public policymakers, families, businesses, health care providers, and social security programmes, among many other issues. In addition to these, is the prospect of smaller labour force having to support an increasing larger older populations, besides the children under 15 years. Older people are generally recognized as one of the poorest, isolated, powerless, low-self esteem, marginalized and therefore most vulnerable groups (HAI 2001; UN 2010; WHO 2002). In Sub-Saharan Africa, older people are a particularly vulnerable social group because of high levels of ravaging poverty, and HIV and AIDS ${ }^{8}$ pandemic that is affecting many of these countries (Caldwell and Caldwell1993; Dayton and Ainsworth 2002). These factors should be taken into account when planning and implementing national developments and aid programmes in Sub-Saharan Africa. The following two related quotations summarize the situation of old age and HIV and AIDS problems generally, and specifically in SubSaharan Africa:-

Table 1: Number of Older People by Age and Region of the World: 2006, 2015, 2030 and 2050 (in thousand)

\begin{tabular}{|c|c|c|c|c|}
\hline Region and Year & Total all ages & $\begin{array}{l}50 \text { years and } \\
\text { over }\end{array}$ & 60 years and over & 80 years and over \\
\hline \multicolumn{5}{|l|}{ World } \\
\hline $2006 \ldots \ldots \ldots \ldots \ldots \ldots$ & $6,525,521$ & $1,271,311$ & 638,334 & 90,014 \\
\hline $2015 \ldots \ldots \ldots \ldots \ldots \ldots$ & $7,225,878$ & $1,620,873$ & 895,032 & 126,465 \\
\hline $2030 \ldots \ldots$ & $8,290,288$ & $2,310,781$ & $1,402,673$ & 214,680 \\
\hline $2050 \ldots \ldots \ldots \ldots \ldots \ldots$ & $9,401,505$ & $3,146,862$ & $2,087.597$ & 466,094 \\
\hline \multicolumn{5}{|l|}{ Europe } \\
\hline $2006 \ldots \ldots \ldots \ldots \ldots \ldots$ & 805,534 & 260,381 & 157,997 & 27,849 \\
\hline $2015 \ldots \ldots \ldots \ldots \ldots \ldots \ldots$ & 809,295 & 294,134 & 180,995 & 35,720 \\
\hline $2030 \ldots \ldots$ & 789,606 & 333,022 & 225,570 & 46,971 \\
\hline
\end{tabular}


Problems of Older People and HIV and AIDS Scourge in Sub-Saharan Africa With Reference to Kenya

\begin{tabular}{|c|c|c|c|c|}
\hline $2050 \ldots \ldots \ldots \ldots \ldots \ldots \ldots$ & 757,294 & 345,725 & 254,079 & 72,020 \\
\hline \multicolumn{5}{|l|}{ North America } \\
\hline $2006 \ldots \ldots \ldots \ldots \ldots \ldots$ & 331,672 & 99,813 & 56,739 & 12,200 \\
\hline $2015 \ldots \ldots \ldots \ldots \ldots \ldots \ldots$ & 358,378 & 123,017 & 73,553 & 13,963 \\
\hline $2030 \ldots \ldots \ldots \ldots \ldots \ldots$ & 403,073 & 147,653 & 102,554 & 21,937 \\
\hline $2050 \ldots \ldots \ldots \ldots \ldots \ldots$ & 461,639 & 173,570 & 122,026 & 37,659 \\
\hline \multicolumn{5}{|l|}{ Oceania } \\
\hline $2006 \ldots \ldots \ldots \ldots \ldots \ldots$ & 33,129 & 8,449 & 4,831 & 907 \\
\hline $2015 \ldots \ldots \ldots \ldots \ldots \ldots$ & 36,450 & 10,423 & 6,266 & 1,112 \\
\hline $2030 \ldots \ldots \ldots \ldots \ldots \ldots$ & 41,139 & 13,694 & 8,857 & 1,795 \\
\hline $2050 \ldots \ldots \ldots \ldots \ldots \ldots$ & 44,761 & 16,962 & 11,468 & 2,959 \\
\hline \multicolumn{5}{|l|}{ Asia } \\
\hline $2006 \ldots \ldots \ldots \ldots \ldots \ldots$ & $3,682,827$ & 685,587 & 353,102 & 37,435 \\
\hline $2015 \ldots \ldots \ldots \ldots \ldots \ldots$ & $4,062,994$ & 904,160 & 486,001 & 58,763 \\
\hline $2030 \ldots \ldots \ldots \ldots \ldots \ldots$ & $4,591,905$ & $1,360,854$ & 816,632 & 113,031 \\
\hline $2050 \ldots \ldots \ldots \ldots \ldots \ldots$ & $5,012,685$ & $1,866,459$ & $1,254,954$ & 279.491 \\
\hline \multicolumn{5}{|c|}{ Latin America/Caribbean } \\
\hline (1) & 561,246 & 96,173 & 50,752 & 6,550 \\
\hline $2015 \ldots \ldots \ldots \ldots \ldots \ldots \ldots$ & 620,603 & 130,641 & 69,366 & 9,469 \\
\hline $2030 \ldots \ldots \ldots \ldots \ldots \ldots . . . . . . .$. & 703,993 & 200,070 & 117,676 & 17,365 \\
\hline $2050 \ldots \ldots \ldots \ldots \ldots \ldots \ldots$ & 764,855 & 284,094 & 186,795 & 39,627 \\
\hline \multicolumn{5}{|l|}{ Near East/North Africa } \\
\hline $2006 \ldots \ldots \ldots \ldots \ldots \ldots$ & 358,323 & 47,884 & 24,497 & 2,549 \\
\hline $2015 \ldots \ldots \ldots \ldots \ldots \ldots$ & 416,978 & 67,005 & 33,796 & 3,896 \\
\hline $2030 \ldots \ldots \ldots \ldots \ldots \ldots$ & 507,550 & 115,045 & 62,179 & 7,252 \\
\hline $2050 \ldots \ldots \ldots \ldots \ldots . . . . .$. & 605,780 & 188,407 & 119,004 & 19,833 \\
\hline \multicolumn{5}{|l|}{ Sub-Saharan African } \\
\hline $2006 \ldots \ldots \ldots \ldots \ldots \ldots$ & 752,970 & 73,025 & 35,415 & 2,524 \\
\hline $2015 \ldots \ldots \ldots \ldots \ldots \ldots$ & 921,181 & 91,492 & 45,056 & 3,542 \\
\hline $2030 \ldots \ldots \ldots \ldots \ldots \ldots \ldots$ & $1,244,024$ & 140,443 & 69,205 & 6,330 \\
\hline $2050 \ldots \ldots \ldots \ldots \ldots \ldots$ & $1,754,492$ & 271,643 & 139,270 & 14,506 \\
\hline
\end{tabular}

Source: Velkoff and Kowal 2007 from the U.S. Census Bureau, International Data Base, 2006. In this table, regions follow the practice of the United Nations.

'Despite the fact that older people are often poor and frail, they not only can contract HIV themselves, but are indirectly significantly affected by AIDS scourge that force some of them to care for orphaned and vulnerable children and persons living with HIV and Aids' (HAI 2001).

'In Africa today, as the HIV/AIDS kills the bread-winners of the family and the communities, large numbers of poor older people are assuming responsibility for bringing up their orphaned and vulnerable grandchildren. ... Of the 36.1 million people with AIDS in 2000, 70 per cent were in sub-Saharan Africa. ... The total number of children under the age of 15 years (13.2 million) who have lost their mothers or both parents to AIDS are living with grandparents' (HAI 2002)

Certainly, Sub-Saharan Africa is not the only region experiencing the twin problems of old age - population ageing, and HIV and AIDS scourge. Various studies and reports from different parts of the world including the USA (Knodel et al 2001), Thailand (Knodel and VanLandingham 2000) indicate that older people, originally treated as an age-cohort not at risk of HIV and Aids ${ }^{9}$, are increasingly being directly infected by HIV and AIDS (Beales 2000; Dayton and Ainsworth 2002; WHO 2002). For example, in the USA, $10 \%$ of all reported AIDS cases occur in the population age group of 50 years and above; while it is $11 \%$ in Europe (Knodel and VanLandingham 2000). However, in Sub-Saharan Africa, the situation of old age, and HIV and Aids scourge is catastrophic. Sub-Saharan Africa has the highest HIV and AIDS prevalence rate and has long carried a high burden of diseases, including from malaria and tuberculosis (Ory 1998; WHO 2002; Velkoff and Kowal 2007). HIV and AIDS pandemic has worsened the situation. In the past, old age (population ageing) was perceived as the problem of the developed countries, today, many developing countries including Sub-Saharan Africa are experiencing highest growth rate of older population (Apt 1997; Bailey and Turner 2002; www.census.gov/pc/www/idnew.tml).Yet, currently in Sub-Saharan Africa, only two countries, South Africa and 


\section{Problems of Older People and HIV and AIDS Scourge in Sub-Saharan Africa With Reference to Kenya}

Namibia, have official programmes for older people such as old age homes, pension and/or social security programmes of significance (Bailey and Turner 2002; Kakwani and Hinz 2006; Kakwani and Subbarao 2005) ${ }^{10}$. In Kenya, and indeed in many of the SubSaharan African countries, old age homes are largely provided by NGOs and churches; and their appropriateness and suitability in addressing old age problems are often questionable ${ }^{11}$. There are a few, if any, government supported old age programmes. In 2008 , Kenya's Retirement Benefit Authority submitted to Cabinet a universal non-contributory pension package designed to provide all older Kenyans from age 55 with a monthly minimum guaranteed benefit; but this has, since been suspended. There is a need to develop appropriate policies and programmes for the older and/or ageing populations in Sub-Saharan Africa.

This paper thus raises three main questions: what are the demographic trends of older people world-wide, in Sub-Saharan Africa, and in Kenya? What are the problems facing older people in Sub-Saharan Africa? How does HIV and AIDS affect the older people in Sub-Saharan African countries? The current HIV and Aids policy and the various institution including the Government, NGOs and other stakeholders do not consider issues on older people when planning mitigation against the pandemic. Older persons are not included in the National HIV and AIDS Strategic Plans of most countries in Sub-Saharan Africa, yet they too get infected and affected. Most HIV and AIDS scourge policy papers do not expressly mention older people. Older people's problems should be integrated into various development and HIV and AIDS programmes in Sub-Saharan African countries, and Kenya in particular.

\section{THE DEMOGRAPHIC TRENDS OF OLDER PEOPLE}

World-wide statistics indicate a change in the human population structure, whereby the population of people aged 50s and $60 \mathrm{~s}$ is the fastest growing cohort (Kinsella and Phillips, 2005; Kinsella and Velkoff, 2007; UN 2010). However, the number of older people and the pace of aging vary widely both by regions and within regions. Typically, more developed countries have higher proportions of their populations in older age groups than do developing countries including Sub-Saharan Africa (See Table 1). For example, nearly $20 \%$ of Europe's population was aged 60 and above in 2006. In contrast, about 5\% of Sub-Saharan Africa's population was aged 60 and over. In all regions, however, the proportion aged 60 is projected to increase (See Table 1). Estimates indicate that the ageing of the population in developing countries including Sub-Saharan Africa will accelerate over the next four decades; and that by 2020, older people will be over 700 million worldwide, almost the current total population of Africa (Adamchak 1989; Apt 1997). By 2050, it is estimated that the proportion of older people will be $21 \%$ of world total population (Dayton and Ainsworth 2002; DFID 1999; Disney 1996).

\section{Old Age Trends in Sub-Saharan Africa}

Population ageing in Sub-Saharan Africa is increasing, albeit slowly than in other developing countries where mortality and fertility have long been declining in the past decades (Dayton and Ainsworth 2002; DFID 1999; Foote et al. 1993; UN 2010). Table 2 shows that by 2050 the proportion of older people in Sub-Saharan Africa is projected to be $8.3 \%$, compared to $23.6 \%$ in Asia, and $24.1 \%$ in Latin America. Developed world regions, being at the end of their demographic transition will continue to have the oldest populations, though their rate of growth will be far slower than in the developing world (Kinsella and Philips 2005; UN 2010; USA 2007). Basically, Sub-Saharan Africa's populations are still at the beginning of the demographic transition, THOUGH IS growing fastest.

Table 2. Projected Population Ageing by Major World Regions

\begin{tabular}{|c|c|c|c|c|c|}
\hline \multirow[t]{2}{*}{ WORLD REGIONS } & \multicolumn{5}{|c|}{$\%$ of total population aged 60 years and above } \\
\hline & 2005 & 2010 & 2025 & 2030 & 2050 \\
\hline Sub-Saharan Africa & 4.9 & 5.0 & 5.5 & 5.8 & 8.3 \\
\hline Asia & 9.3 & 10.4 & 14.9 & 16.6 & 23.6 \\
\hline Latin America & 8.8 & 9.5 & 14.5 & 17.3 & 24.1 \\
\hline North America & 16.8 & 18.2 & 24.2 & 25.8 & 27.0 \\
\hline Europe & 20.7 & 22.67 & 28.0 & 30.2 & 34.5 \\
\hline World & & & & & \\
\hline
\end{tabular}

\section{Sources: United Nations 2005}

\section{Old Age Regional Variations within Sub-Saharan Africa}

Within the Sub-Saharan Africa region, estimates show that the rate of population ageing vary slightly between and within regions (Table 3). For example, there will be rapid and higher growth rate of 60 and above old in Southern and West Africa, and slower expansion in Central and East Africa. Despite the relative 'youth' of its populace and its comparatively slow pace, population ageing in Sub-Saharan Africa presents a real and important challenge, which societies and governments must recognize and begin to address now. This is because, many countries in Sub-Saharan Africa, especially those most severely affected by HIV and AIDs epidemic may see a sudden surge in premature population ageing. In the process, they may experience a sharp rise in older people's 


\section{Problems of Older People and HIV and AIDS Scourge in Sub-Saharan Africa With Reference to Kenya}

share of the total population, resulting from the disproportionate death of prime-aged adults from the disease (United Nations, 2010). At the same time, older people in sub-Saharan Africa, once they have reached 60 years, can expect to live many more years, almost as long as older people in other regions. Life expectancy at age 60 and 80 in SSA does not dramatically differ from that in other developing or even developed world regions (See Table 5). There is also the increasing search for HIV and AIDS cure and the success of antiretroviral which now enable infected people to live longer.

Table 3. Regional Variations in rate of Population Ageing by Major Regions in Sub-Saharan Africa

\begin{tabular}{|l|l|l|l|l|l|}
\hline \multirow{2}{*}{$\begin{array}{l}\text { SUB-SAHARA AFRICA } \\
\text { REGIONS }\end{array}$} & \multicolumn{5}{l}{$\%$ of Total Population Aged 60 and above } \\
\cline { 2 - 6 } & 2005 & 2010 & 2025 & 2030 & 2050 \\
\hline Central Africa & & & & \\
\hline East Africa & 4.6 & 3.7 & 2.3 & 3.4 & 8.2 \\
\hline Southern Africa & 4.6 & 4.9 & 5.1 & 5.8 & 8.1 \\
\hline West Africa & 6.7 & 9.2 & 11.0 & 4.4 & 8.8 \\
\hline
\end{tabular}

Sources: UN 2002 World Population ageing 1950-2050

\section{The Age Structure in Kenya}

The population of Kenya, much the same as in other Sub-Saharan African countries, is generally young, with $42.9 \%$ under 15 years old by 2000 (Kakwani and Hinz 2006). Persons over 60 years old comprised only $3.8 \%$ of the total population; but is projected to be $5 \%$ by 2025 and $12.7 \%$ by 2050 (See Table 4 ). There is a large proportion in the age group $0-14$ which gradually diminishes in the subsequent age groups. The proportion of both women and men decline with increasing age, reflecting the comparatively young age structure of Kenyan population. Slightly less than half of the population is under 15 years of age, whereas only $4-5 \%$ are above 60 years. Today, it is about $4.5 \%$ and is projected to be $12.7 \%$ of the total population, about $20 \%$ of the working age population. In Africa today, older people (60 and above) make up between 3\% and 5\% of total African population (Apt 1997; Kakwani and Hinz 2006).

Table 4. Age Structure of Population in Kenya in 2000, 2010, 2025 and 2050 Estimates

\begin{tabular}{|l|l|l|l|l|}
\hline$\%$ Shares of population & 2000 & 2010 & 2025 & 2050 \\
\hline Children (Under 15 years old) & 42.9 & 44 & 31.0 & 23.0 \\
\hline Adults (between 16-59 years old) & 53.3 & 56.2 & 64.0 & 64.3 \\
\hline Elderly (60 years old and above) & 3.8 & 4.3 & 5.0 & 12.7 \\
\hline Total Population & 100.0 & 100.0 & 100.0 & 100.0 \\
\hline
\end{tabular}

Sources: US Census Bureau (International Data Base). Kenya National Population Census 2009.

\section{The Old Age Kenya}

The population of the elderly in Kenya has tremendously increased in recent years. For example, those aged 55 years and above increased from 1.54 million in 1994 to 1.76 million in 1997 (Kakwani and Hinz 2006). According to the National Population Census of 2009, Kenya currently has about 1.5 million people aged 60 and above, constituting 4.8 per cent of the population. By 2050 , Kenya will have 3.5 million. Those aged 60 and above rose from 1.09 and 1,25 million in 1994 and 1997, respectively. In general, a greater percentage of older people live in rural areas than in urban areas, and in poor households than in non-poor households (Table 5). Table 5 indicates the number of elderly persons within the various categories of households and also shows the percentage change. Those aged 55 years and above increased from 1.54 million in 1994 to 1.76 million in 1997. Those aged 60 and above rose from 1.09 and 1,25 million in 1994 and 1997, respectively.

\section{Old Age Regional Variations within Kenya}

Within Kenya, as common in other Sub-Saharan African countries, the populations of older people vary by regions, counties and provinces and in urban and rural areas. Reports and statistics indicate that Nyanza province is the most populous province for the elderly in all years 1994 and 1997 and 2009 (Kakwani and Hinz 2006; KNBS 2010). On the other hand, the least populous province is the Northeastern province. A greater percentage of the elderly population in Kenya lives in rural areas and older people reside relatively more in poor households compared to non-poor households; a greater percentage of older people live in rural areas than in urban areas, and in poor households than in non-poor households. 
Problems of Older People and HIV and AIDS Scourge in Sub-Saharan Africa With Reference to Kenya

\section{PROBLEMS OF OLDER PEOPLE}

Traditionally treated as a problem only for the developed countries, old age is increasingly becoming an issue in SubSaharan Africa, and Kenya, in particular. Older people have their own distinct problems; ranging from health issues to economic, social and lack of policy systems and general insecurity and neglect of the elderly (Masinde 2009; Kivela el al. 1992; Wamalwa 2000). On health problems, older people suffer from blindness, deafness, arthritis, and many other old age diseases (Kalasa 2004; Kinsella and Victoria 2001). The elderly, generally, become ill more frequently than other age cohorts. Other examples of agingassociated diseases are cardiovascular disease, cancer, cataract, rheumatism, osteoporosis, type 2 diabetes, hypertension and Alzheimer's disease. The incidence of all of these diseases increases rapidly with aging (Kinsella and Victoria 2001). Most older people have to live with more chronic diseases or problems, and are generally trying to fight against several health problems at once, resulting in an increase in the number of medications taken and general restrictions of daily activities, amongst others.

In addition to health problems, reports indicate that older people comparatively experience more serious socio-economic and cultural difficulties (Apt 1997; Vatuk 1996). Recent studies indicate that the majority are poor. They are unemployed. Despite the socioeconomic difficulties they face, older people in most Sub-Saharan countries including Kenya no longer receive much of the support the young generation provided them (Velkoff and Kowal 2007; Vatuk 1996). In the past, issues such as poverty amongst the local people, especially the marginalized groups such as the older persons, women and children in the rural areas, were communally taken care of; but today, very few people pay attention to such marginalized groups, least of all, older people (Velkoff and Kowal 2007). Older people in Africa were perceived to play important roles in the families and in the society (Apt 1997; Keizi 2008; Vatuk 1996; van de walle 2006). They were valued for their wisdom; they were cared for, they had power. They were the mainstay of the family and the entire society, managing property, money and resources. The young needed them to get married, to choose names for their children, to get apprenticed and so on (Apt 1997; Help-Age 2002). Older people were entrenched within their families. Today, however, all these perceptions of older people and their roles, are changing, the older people are losing power (Dayton and Ainsworth 2002; DFID 1999; Disney 1996; Apt 1997; Vatuk 1996). With modern western education system, the roles have been jobs and money. Younger people no longer need their grandparents to find them a wife, or in some cases, to pay a dowry. As a result, the power and value of older people in the societies have been eroded (Dayton and Ainsworth 2002; DFID 1999).

The increasing HIV and Aids scourge necessitating increase in the number of orphan children now depending on the aging grandparents further worsens the health conditions and the food inadequacy situation for the elderly. The elderly also do not often use private hospital/clinics. Equally important, older people lack suitable information on health conditions. There is also the social stigma due to general negative attitudes towards ageing and the older people. They also lack security and protection in old age, especially if the old people can't take care of themselves financially, especially old women ${ }^{12}$. In some cases, older people face death due to beliefs of witchcraft which is widespread across Sub-Saharan Africa (Apt 1997; Vatuk 1996). Many older people have been attacked and sometimes killed for practicing witchcraft. It is estimated that some 1,000 old people in Tanzania lose their lives annually due to witchcraft-related violence, the majority being women over the age of 50. Older people are becoming more vulnerable and isolated, and live in deplorable housing conditions, their healthcare and social facilities are inadequate ${ }^{13}$ (Help-Age 2002; van de walle 2006). Most importantly, currently there is no policy on old age in most Sub-Saharan African countries, including Kenya.

\section{HIVAND AIDS SCOURGE}

HIV and Aids, is, indeed, a global problem, posing an unprecedented development and human challenges; but in SubSaharan Africa, it is a disaster. Inhabited by just over $12 \%$ of the world's population, Sub-Saharan Africa is estimated to have by 2005 more than $60 \%$ of the World's AIDS-infected population (Joint United Nations Programme on HIV/Aids 2006). The region is more heavily affected than any other region of the World. An estimated 30 million people are living with HIV in the region which is about two thirds (68\%) of the global total of HIV and Aids cases, which at the end of 2009 to be about 33.3 , up slightly from 32.8 million in 2008 (Knodel and Velkoff 2001; Kinsella and Velkoff 2001; UNAIDS and WHO 2008). In Kenya, about 8\% of people aged 50-54 are living with HIV. This is higher than the national prevalence rate (Government of Kenya, Kenya AIDS Indicator Survey 2007).

In 2008, about 1.4 million people died from AIDS in sub-Saharan Africa and 1.9 million people became infected with HIV. Seventy-percent of adults and $80 \%$ of children living with HIV in the world are in Sub-Saharan Africa. Since the beginning of the epidemic more than 15 million children have lost one or both parents to AIDS and the majority is in Sub-Saharan Africa. In Kenya, as in many other countries of Sub-Saharan Africa, the epidemic has cut life expectancy to less than 60 years; and robbed societies of millions of people in their prime working years (Table 5) (Knodel and Velkoff 2001; Kinsella and Velkoff 2001; UNAIDS, 2006). 
Problems of Older People and HIV and AIDS Scourge in Sub-Saharan Africa With Reference to Kenya

Table 5. Projected Life Expectancy in Kenya, with and without AIDS, 1980-2010

\begin{tabular}{|l|l|l|l|l|l|l|}
\hline Status & $1980-1985$ & $1985-1990$ & $1990-1995$ & $1995-2000$ & $2000-2005$ & $2005-2010$ \\
\hline Without HIV & & & & & & \\
Male & 58.8 & 60.3 & 61.3 & 62.3 & 63.2 & 63.2 \\
Female & 66.5 & 66.7 & 67.9 & 69.1 & 70.2 & 71.1 \\
With HIV & & & & & & \\
Male & 58.7 & 59.6 & 56.2 & 51.0 & 51.4 & 55.7 \\
Female & 66.2 & 65.9 & 63.0 & 56.4 & 55.5 & 61.0 \\
\hline
\end{tabular}

Source: Kenya National Bureau of Statistics (Statistical Abstract) 2010.

The epidemic varies from one region to another and over time within Sub-Saharan Africa. In the 1980s and early 1990s the epidemic was experienced mostly in Eastern and Central Africa, where the HIV prevalence of women attending antenatal clinics were as high as 30\% in some sites in Uganda (Apt 1997; Ferreria et al. 1992). Since the late 1990s the epidemic increased rapidly in the Southern African countries with record high prevalence of 35.8\% in Botswana, 23.6\% in Lesotho, 16\% in Malawi, 13.2\% in Mozambique, $19.5 \%$ in Namibia, 19.9\% in South Africa, 25.3\% in Swaziland, 20\% in Zambia, and 25.1\% in Zimbabwe (Apt 1995).

Kenya, like many African countries, is currently being devastated by the HIV and AIDS epidemic. Every citizen of Kenya is at risk. Although, the reported AIDS cases in Kenya are heavily concentrated in the age range 20 to 49, but in recent years the number of older people are increasing (UNAIDS, 2006). There is also the possibility that the numbers of AIDS cases among older people in Kenya and most other Sub-Saharn African countries, are underestimated, due to lack of data, but also since health officials are probably less like1y to consider older persons not to be at risk of the disease and thus may not diagnose AIDS as readily for an older person as for a younger adult (Nyambedha et al., 2001; Ochieng', 1985; Ocholla-Ayayo, 1999). In addition, given the substantial lag between initial infection and onset of symptomatic of AIDS, risk behavior at ages younger than 50 can lead to AIDS-related illness after age 50. At the same time, as therapies that extend the survival of HIV positive persons become available and more widely adopted, more people with Aids will be surviving to older ages.

Table 6. Estimated HIV Prevalence Rates, 1998-2010

\begin{tabular}{|l|l|l|l|l|l|l|l|l|l|l|l|l|l|}
\hline YEAR & 1998 & 1999 & 2000 & 2001 & 2002 & 2003 & 2004 & 2005 & 2006 & 2007 & 2008 & 2009 & 2010 \\
\hline HIV RATE & 9.80 & 9.20 & 8.68 & 8.02 & 7.35 & 6.70 & 6.09 & 5.54 & 5.06 & 4.64 & 4.30 & 4.01 & 3.79 \\
\hline
\end{tabular}

Source: Kenya National Bureau of Statistics (Statistical Abstract) 2010.

\section{EFFECTS OF HIV AND AIDS ON OLDER PEOPLE}

HIV and Aids affect older people in two main ways: it poses a direct infection risk and it also places a burden on them as carers. First, it affects older people directly. Although old people have been treated as a cohort not at risk, and therefore generally ignored in the fight against HIV and AIDs, they too get directly affected ${ }^{14}$. Recent studies in Kenya have found that many of the older people, age 50 and above, are still sexually active, but may not be practicing safer sex to reduce their risk for HIV infection. For example, HIV prevalence among people aged between 50 and 60 is 5 percent, compared with a national average of 7.1 percent, meaning that the older population are actually at risk of contracting HIV ${ }^{15}$ (NASCOP 2007). The number of older people diagnosed with AIDS is increasing worldwide. There are three types of older people with HIV (a) people who have been living with HIV for many years; (b) older HIV-infected people who are just learning their HIV status; and (c) older people newly infected with HIV. About half of the older people with AIDS have been infected for one year or less, meaning that they were recently affected. Besides, some of the older people view condoms primarily as a contraceptive measure and are therefore likely to engage in unprotected sex. Older women, in particular, who no longer fear unwanted pregnancy may not insist on the use of condoms. In some studies, it was found that compared with younger persons, only one-sixth of people over the age of 50 are likely to use condoms. Older women may also be, especially at risk because of age-related vaginal thinning and dryness that may cause tears in the vaginal area, making them more vulnerable to HIV. In the postmenopausal stage, their vaginal walls are thinner and lubrication is often reduced. Many doctors believe older women are more vulnerable to vaginal trauma during intercourse, and are thus at greater risk of contracting HIV.

In addition, a number of older people are newly single, some get widowed, divorced or lose their mates. In addition, there is an increase of sexual performance enhancers such as viagra and other drugs that help men get and maintain an erection. This may contribute to increased rates of sexual activity and sexually transmitted diseases among older people, as they do for younger people. Some older persons inject drugs or smoke crack cocaine, which can put them at risk for HIV infection. There is also an increased number of younger girls preferring older men, especially for money; older people have more money (compared to younger unemployed men), hence attracting young girls through increased prostitution. In some case, younger girls who may have been HIV infected marry older men, in societies that practice polygamy or after the deaths or divorce. The rate of divorces or separations are also increasing in Sub-Saharan Africa. Some reports indicate that many older people when they get new partners often ignore HIV prevention messages; with some older people believing that HIV only affects younger people. 


\section{Problems of Older People and HIV and AIDS Scourge in Sub-Saharan Africa With Reference to Kenya}

Despite direct effects of HIV and AIDS on older people, currently, education campaign on the disease does not target older people. Yet, many older people, especially women past menopause, engage in unprotected sexual activity. In addition reports indicate that health care providers may not test older people for HIV infection. It is also difficult for physicians to diagnose HIV infection in older people; because some early symptoms of HIV disease may appear to be signs of normal aging such as fatigue, weight loss, and mental confusion; even skin changes. Most other old age diseases such as alzheimer's disease, arthritis, diabetes, breast cancer, prostate cancer, high blood pressure, vision loss and hearing loss; all share similar symptoms with HIV. It is also believed that stigma of having HIV and AIDS may be worse for older people; resulting into hiding their infection from family and friends. Failure to disclose HIV infection may limit or preclude potential emotional and practical support.

Secondly, HIV/AIDS indirectly places several burdens on older people as carers, and also puts them at risk of infection. Many older people provide home-based care for people living with AIDS, but are not directly targeted by prevention and awareness campaigns. Older people are caring for the sick, the dying and the children orphaned or made vulnerable by HIV and AIDS pandemic; yet they lack knowledge of how to treat the disease and protect themselves against infection. In sub-Saharan Africa, about 14 million children have lost one or both parents to HIV and AIDS. Many of these orphans now live in grandparent-headed households. As evidenced in this quote:

"The lives of the older people may be affected by their own illness, but it is more likely, given the age structure of the pandemic, that they are affected by sickness and death of their adult children. Not only do these older people face the loss of a child or children who may well have been a vital source of support and care giving, but many are also then faced with additional obligations and responsibilities for grandchildren and other members of their extended families" (HAI 2001)

Older people have to meet the costs of daily living - providing food and clothes, as well as funding their grandchildren's education. They now assume the responsibility of bringing up the orphans and vulnerable children. As a result, they face a variety of financial difficulties. Some of the older people may need to liquidate their financial assets (including land) to pay for the living and medical expenses of the sick family members. They have limited access to health care and education services; and hardly exposed to HIV and AIDS awareness programmes. In some cases, the older person may need to stop or curtail working to help care for the people living with aids (PWA); and this could have serious negative consequences for the financial well-being of the older person. Due to their roles as caregivers to people living with AIDS, who in most cases are adult sons and daughters, and orphaned grandchildren, the older people get fatigued - including exhaustion, grief and emotional upheaval, conflicts with grandchildren, social stigma and discrimination and exclusion from information and support services. Many older people in HIV-affected households suffer poor physical and mental health through increased care-giving workloads. They can also suffer feelings of blame, shame and guilt about their children's situation. Studies and reports show that the financial and social burdens on older people who care for grandchildren is, in short, immense (Ferreria et al. 1992; Knodel, J. et al., 2001; HelpAge International, 2002; UNAIDS, 2006; UNICEF, 2003).

It is important to note that HIV in Older people are not the same as in younger people. For example, reports indicate that CD4 cell levels do not recover as quickly in older patients as in younger patients. However, there is no adequate researched information on older people because they were usually not included in clinical trials of new drugs. Nonetheless, older people could probably get sicker and die faster than younger people due to their weaker immune systems. At the same time, treatment of side effects of HIV and AIDS may not be easily noticeable in older people because the effects of changes caused by aging can resemble or worsen treatment side effects. For example, older age is a major risk factor for heart disease and for increasing fat in the abdomen. Some older people without HIV lose fat that looks similar to the changes caused by lipodystrophy. Some studies suggest that many of the health problems of older people may progress faster in older people with HIV. Older people often take many different medications to deal with their health problems. This can make it more difficult for a doctor to choose anti-HIV drugs because of interactions with other medications. However, recent research and reports show that older people respond well to antiretroviral treatment. Most older patients, unless they are drug users or have mental problems, take their medications more regularly than younger patients. They have better adherence.

\section{DISCUSSIONS}

The aging of the community brings with it new and serious problems both nationally and internationally, with WHO (2002) describing it as an important developmental element requiring emergency action. Sub-Saharan Africa faces a greater set of development challenges with older people and HIV and AIDS than any other region of the world, and, on average, income per capita is now lower than it was at the end of the 1960s (World Bank 2006; Apt 1997). It is estimated that 516 million people in the region are forced to survive on less than $\$ 2$ a day, and 303 million on less than $\$ 1$ a day (World Bank 2006). The number of extremely poor people (of which older people forms a significant) in Sub-Saharan Africa has almost doubled since 1981 (World Bank 2006). Sub-Saharan Africa is home to a growing share of the world's absolute poor (United Nations 2010). Lack of or declines in support for older people would worsen the impacts of poverty in various communities in SSA (Caldwell and Caldwell 1993; Cohen 1993). There is need for a comprehensive formal social security system in the absence of a well-functioning traditional care system in place, and in the light of catastrophic health crisis with neither. On the other hand, many older people continue working for a living 


\section{Problems of Older People and HIV and AIDS Scourge in Sub-Saharan Africa With Reference to Kenya}

well after retirement. As a result, older people should not be viewed merely as dependents, but as partners in development. Their role should be recognized, as they work hard and contribute to the economy. It is important to involve older people in the HIV and AIDS project planning, implementation, monitoring and evaluation. As the Chief Executive Officer of Help Age International noted "older people are

"the forgotten and invisible army in the war against AIDS. If we don't want to have more orphanages and children on the streets, we have to help older people care for and love their grandchildren." He called for an intergenerational approach in tackling the orphan crisis in Africa.

Older people in the rural areas should be included as counsellors and educators of HIV/Aids in National and CBOs program. The role of older people and their contribution to society, their wealth of experience and knowledge need to be recognized. The old people's rights, needs and contributions must be well understood. As is it, today, in Sub-Saharan Africa, there is almost no legal or policy framework to safeguard the rights of elderly (Apt 1997; Bailey and Turner 2002; Barrientos 2002; Barrientos et al 2003; Beales 2000). There is lack of data on old age. The rights of the elderly are usually last on the agenda when it comes to the protection of the human rights of a population as a whole.

The number of persons aged 50 years and older living with HIV and AIDS has been increasing in recent years. This increase is partly due to highly active antiretroviral therapy (HAART), which has made it possible for many HIV-infected persons to live longer, and partly due to increased newly diagnosed infections in persons over the age of 50. As the population continues to age, it is important to be aware of specific challenges faced by older people and to ensure that they get information and services to help protect themselves from HIV infections. Older people should have access to information on the risk of HIV and AIDS, so that they can protect themselves and others against infection. They also need emotional support to help them deal with the stigma and discrimination that result from having a child or grandchild with HIV and AIDS. They also need psychosocial coping mechanisms to deal with stress, illness and grief and other difficulties. Institutionalization, building of old people's homes, may not be entirely applicable Africa, except for the ailing. Community-based - out-reach home care programmes. There is need to put up structures and help integrate the old into the community. Caring for the elderly people involves looking at the community in its broadest context. The older people should be empowered to continue being productive and participate in income generating and general development activities. Older people should be assisted towards meeting the households' costs including food and healthcare; providing education and clothing for grandchildren; for treatment and travel to clinics to care for sick children; and to compensate for loss of earnings or family support. There is need for mutually supportive relationships between older carers and orphans and vulnerable children to respond to the difficult economic conditions. The advantages of keeping children with their remaining family members, whenever possible, are evident and should be encouraged within the context of African extended family systems.

\section{CONCLUSIONS AND RECOMMENDATIONS}

In many Sub-Saharan African countries including Kenya, impacts of the rapidly expanding old age and HIV and AIDS scourge is causing strain to the elderly and the general economy of those countries; most of which are still poor. This paper has assessed the twin problems of HIV and AIDS and the old age problems in Sub-Saharan Africa with reference to Kenya. World-wide statistics indicate a change in the human population structure, whereby the population of people aged 50s and 60s is the fastest growing age-cohort. This trend, formerly perceived to be for the developed countries, has now caught up with developing countries and SubSaharan Africa posing more problems in the era of HIV and Aids scourge and the devastating poverty. HIV and AIDS is growing rapidly amongst older people and is expected to continue increasing. As a result, older people in Sub-Saharan Africa are facing various direct and indirect problems in the light of increasing impacts of HIV and AIDS scourge. Some of the difficulties facing the elderly include:-

(1) Loss of economic support, particularly the loss of remittances from their sick and/or dead adult children,

(2) Lack of access to basic needs such as food and clothing;

(3) Limited access to and utilization of health care services due to transport difficulties and the high cost of services;

(4) Financial hardships leading to inability to pay for medical or school fees;

(5) Negative attitudes of health workers towards the older care providers, both as older persons and as people living with HIV and AIDS;

(6) Stigmatization of the disease by the community and by service providers;

It is predicted that many countries in Sub-Saharan Africa will experience a relative increase in its older HIV-positive population, an increase in the number of new HIV infections, and a greater proportion of people with HIV living outside major metropolitan areas by 2020. There are needs for well organized structures and training to be simplified for people coming through in aged care or other services. If international commitments on HIV and AIDS and poverty reduction are to be met and the problems of old age given serious attention, the Governments of Sub-Saharan African countries, international organizations, national Governments' agencies, NGOs, churches should increasingly:

(1) Reduce the stigma surrounding the sexual needs of older people and encourage them to discuss these issues with their health providers and families; 


\section{Problems of Older People and HIV and AIDS Scourge in Sub-Saharan Africa With Reference to Kenya}

(2) Educate healthcare providers about the sexuality and sexual practices of older people to allow for improved communication and more accurate risk assessment;

(3) Integrate HIV programming into services for older persons, including secondary prevention education (prevention among HIV-positive people), into specialized care services;

(4) Educate HIV service providers on the need to provide age-sensitive services and the specific issues related to HIV in an ageing population; Identify areas of research specifically looking into the interactions between age and HIV;

(5) Provide direct income support to address the financial needs of older carers of orphans and vulnerable children.

(6) Ensure policies and programmes ${ }^{16}$ designed to meet the health needs of families affected by HIV and AIDS include older people and orphans and vulnerable children.

(7) Ensure access to universal and flexible education services for orphans and vulnerable children that recognize their changing roles, time commitments and financial constraints.

(8) Provide older people with information and training on HIV and AIDS and the rights of children and older people.

(9) Develop policies and programmes that address the psychosocial needs of older carers and orphans and vulnerable children.

(10) Ensure the involvement and participation of older carers and orphans and vulnerable children, in community structures, and in formulating national policy for poverty reduction and supporting families affected by HIV and AIDS. Strengthen community based care mechanisms to ensure that older people who are carers of those affected by AIDS and other epidemics receive support.

(11) Undertake research and collect comprehensive age-disaggregated data on the needs and roles of older people and orphans and vulnerable children, to design HIV and AIDS interventions that are inclusive of older people. Such researches should cover general issues of older people and HIV and AIDS scourge focusing on a national survey of old people's health, socioeconomic and living conditions; assess the vulnerability of older people to HIV and AIDS scourge, and establishment whether the impacts on the older population are direct (the older person is infected) and/ or indirect (the older person is affected via the infection of significant others).

(12) Providing concrete support to older people (for example social pensions); training HIV and AIDS service and health providers on gerontological issues; providing psychological and medical support for older people living with ill family members; include older people in HIV and AIDS education/training programmes.

Last, but not least, the Governments of Sub-Saharan African countries, international organizations, national Governments' agencies, NGOs, churches should observe and honour declarations made at international and continental summits ${ }^{17}$ touching on HIV and AIDS scourge and issues of the old age including:

(1) The Declaration of Commitment on HIV and AIDS signed at the United Nations General Assembly Special Session (2001) committed member states to implement by 2005 'national policies and strategies... [that] provide a supportive environment for orphans and girls and boys infected and affected by HIV and AIDS.' It further committed governments to 'review the social and economic impact of HIV and AIDS at all levels of society, especially on women and the elderly, particularly in their role as caregivers.

(2) The Madrid International Plan of Action on Ageing (2002) also committed member states to 'introduce policies to provide... support, health care and loans to older caregivers to assist them in meeting the needs of children and grandchildren in accordance with the Millennium Declaration.'

(3) The Millennium Development Goals commit UN member states to halving, by 2015, the number of people living in extreme poverty and halting and reversing the spread of HIV and AIDS.

(4) An overview of the issues identified by older people and orphans and vulnerable children themselves;

(5) Declaration of Commitment on HIV and AIDS. Global crisis - global action, United Nations General Assembly Special Session on HIV and AIDS, New York, 2001, Articles 65 and 68 respectively.

(6) Madrid International Plan of Action on Ageing 2002, United Nations Report on the Second World Assembly on Ageing, 8-12 April 2002,A/CONF.197/9, Paragraph 81 (b).

(7) Implement the African Union Policy Framework and Plan of Action on Ageing and the UN Madrid Plan of Action on Ageing.

\section{REFERENCES}

1) Adamchak, D.J. 1989. 'Population aging in Sub-Saharan Africa: the effects of development on elderly'. Population and Environment, 10 (3): 162-176.

2) Apt, Nana Araba 1997. Ageing in Africa. Geneva: World Health Organization.

3) Bailey, C., and Turner, C. (2002). Social security in Africa: A brief review. Journal of Aging and Social Policy, 14(1), 105-114.

4) Barrientos, A., Gorman, M., and Heslop, A. (2003). Old age poverty in developing countries Contributions and dependence in later life. World Development, 31(3), 555-570. 


\section{Problems of Older People and HIV and AIDS Scourge in Sub-Saharan Africa With Reference to Kenya}

5) Barrientos, A. 2002. Old age Poverty and Social Investment, Journal of International Development, Vol. 14, No. 8, PP. 1133-1142.

6) Beales, S; 2000 The impact on older people of HIV/AIDS in developing countries; implications for research, policy and development aid. Submission to the International Development Committee.

7) Caldwell, J. C., \& Caldwell, P. 1993. The nature and limits of the sub-Saharan African AIDS epidemic: Evidence from Geographic and other Patterns. Population and Development Review, 19, 817-848.

8) Dayton, J. and M. Ainsworth 2002. The Elderly and Aids: Coping Strategies and Health Consequences in Rural". Population Council, Policy Research Division, Working Papers, No. 160.

9) DFID 1999. Ageing and Development. HelpAge International, Social Development Department, Working Paper No. 3

10) Disney, R. 1996. Can we Afford to Grow Older? A Perspective on the Economics of Ageing. Cambridge: MIT Press.

11) Foote, Karen A., Kenneth H. Hill, and Linda G. Martin (eds.) 1993. Demographic Change in Sub-Saharan Africa, National Academy Press, Washington, DC.

12) Help Age International, 2001. HIV/AIDS: why strategies must include older people, Ageing and Development Newsletter No. 8, Help Age International, May 2001.

13) Help Age International 2002. Ageing Issues in Africa: A Summary. Africa Regional Development Centre International Strategy for Action on Ageing http://www.un.org/esa/socdev/ageing/waa/index.html

14) Juma, M., T. Okeyo, and G. Kidenda. 2004. "Our hearts are willing, but... Challenges of elderly caregivers in rural Kenya," Horizons Research Update. Nairobi: Population Council.

15) Kakwani, Nanak, and Kalanidhi Subbarao (2005). Ageing and poverty in Africa and the role of social pensions. International Poverty Centre Working Paper, No. 8. August. Brasília: United Nations Development Programme International Poverty Centre.

16) Kakwani Nanak, H.H. Son and Richard Hinz 2006. Poverty, Old Age and Social Pensions in Kenya, UNDP.

17) Kenya National Bureau of Statistics (KNBS) 2011. Statistical Abstract 2010. Republic of Kenya, Nairobi

18) Kenya National Bureau of Statistics (KNBS) 2010. 2009 Kenya Population and Housing Census, Counting Our People for the Implementation of Vision 2030, Republic of Kenya, Nairobi

19) Kinsella, Kevin and David R. Phillips, 2005, Global Aging: The Challenge of Success, Population Bulletin 60, No. 1, Population Reference Bureau, Washington, DC.

20) Kalasa B (2004) Population and Ageing in Africa: a Policy Dilemma in the 21st Century. Implications for development and programming Working Paper 2000 - 2050

21) Kinsella K. \& Velkoff V. (2001) An Ageing World: 2001 U. S. Census Bureau series P95/01-1 Government Printing Office, Washington DC.

22) Kinsella, Kevin and David R. Phillips, 2005. Global Aging: The Challenge of Success, Population Bulletin 60, No. 1, Population Reference Bureau, Washington, DC.

23) Kinsella, Kevin and Victoria A. Velkoff, 2001. An Aging World:2001, U.S. Government Printing Office, Washington, DC.

24) Kinsella, Kevin, and David R. Phillips (2005). Global aging: the challenge of success. Population Bulletin (Population Reference Bureau, Washington, D.C.), vol. 60, No. 1 (March).

25) Kivela, S.L., el al. (1992). Abuse in old age: epidemiological data from Finland. Journal of Elder Abuse \& Neglect, vol. 4, No. 3, pp. 1-18.

26) Knodel, J. et al., 2001. Older People and AIDS: Quantitative Evidence of the Impact in Thailand', Social Science and Medicine, 52:9, 2001, pp. 1,313-1,327

27) Knodel J; VanLandingham M.2000;"Children and older persons: AIDS' unseen victims" American Journal of Public Health. $2000 \mathrm{Jul}$; 90(7):1024-5.

28) Masinde, Jamin R.M. 2009. Violence and Abuse among the Elderly in Kenya: Experiences from Rural Communities. MAARIFA - A Journal of Humanities and Social Sciences, Vol. 3:2 97-103.

29) Monasch, R. and J. T. Boerma 2004. Orphanhood and Childcare Patterns in Sub-Saharan Africa: An Analysis of National Surveys from 40 Countries, AIDS 18 (suppl. 2): S55-S65.

30) Mullan. J. T. (1998). Aging and informal caregiving to people with HIV I AIDS. Research on Aging. 20, 7 J2-738.

31) Nyaga, R.K., N. Kimani, G. Mwabu and M.S. Kimenyi 2004. HIV/AIDS in Kenya: A Review of Research and Policy Issues, KIPPRA Discussion Paper No. 38, Nairobi.

32) Omondi, Paul forthcoming Ageing in Sub-Saharan Africa - The Changing Demography and Need for Further Research in Kenya

33) Ory.M. G., Zablotsky, D., \& Crystal, S. (1998). HIV/AIDS and aging: Identifying and prevention research and care agenda. Research on Aging, 20. 637-652.

34) Randel, J., German, T. and Ewing, D. (Eds.). 1999. The Ageing and Development Report: 


\section{Problems of Older People and HIV and AIDS Scourge in Sub-Saharan Africa With Reference to Kenya}

35) Poverty, Independence and the World's Older People. London: Earthscan Publications Ltd.

36) Nairobi Kenya sep. 16, 2003; conference on" The role played by older people in caring for orphans infected with HIV/AIDS"

37) National Aids/STI Control Programme (NASCOP), Kenya 2007. Kenya AIDS Indicator Survey, Final Report, Nairobi, NASCOP, September 2009.

38) Preston, Samuel H., Christine Himes, and Mitchell Eggers, 1989, "Demographic Conditions for Population Aging," Demography, Vol. 26, No. 4, pp. 691-704.

39) Tout, Ken 1989. Ageing in Developing Countries. Oxford University Press

40) UNICEF 2003. Africa's Orphaned Generations, UNICEF. UNICEF, UNAIDS, USAID, 2004. Children on the Brink. UNICEF

41) United Nations 2010. World Population Ageing 2010 (ESA/P/WP/212)

42) United Nations 2002. Madrid International Plan of Action on Aging 2002, Madrdid.

43) United Nations (1982). Report of the World Assembly on Ageing, Vienna, 26 July to 6 August 1982. Sales No. E.82.I.16, chap. VI, sect. A. Also available from http://www.un.org/esa/ socdev/ageing/ageing/ageipaa.htm.

44) United Nations 1997. Older Persons in Countries with Economies in Transition: Designing a Policy Response. Guidelines for Practical Strategies. Sales No. E.96.IV.12.

45) U.S. Census Bureau, International Data Base, 2007. <www.census.gov/ipc/www/idb>

46) Velkoff, Victoria and Paul R. Kowal 2007. Population Aging in Sub-Suharan Africa: Demographic Dimensions 2006, US Government Printing Office, Washington, DC.

47) Wamalwa, J.M. 2000. The Welfare of the Elderly in Contemporary Kenya. Catholic University of East Africa, Nairobi

48) Whipple, B., \& Scura, K. (1989)."HIV and the older adult: Taking the necessary precautions "Journal of Gerontological Housing, 15, 15-19.

49) WHO 2002. The Impact of AIDS on Older People in Africa: Zimbabwe Case Study, Ageing and Life Course, NonCommunicable Disease Prevention and Health Promotion, WHO, Geneva. World Economic and Social Survey 2007. Mplications of Ageing for Social and Economic Development WHO 2002. The Impact of AIDS on Older People in Africa: Zimbabwe Case Study, Ageing and Life Course, Non-Communicable Disease Prevention and Health Promotion, WHO, Geneva, 2002.WHO, September 2001."Impact of AIDS on Older People, Zimbabwe Case Study" HAI/WHO. (Draft)

50) Williams, A. and G. Tumwekwase 2001. Multiple Impacsts of the HIV/AIDS Epiendemic on the Ages in Rural Uganda. Journal of Cross-Cultural Gerontology, Vol. 16.

51) www.un.org/esa/population/unpop.htm Provides access to extracts from the United Nations' World Population Prospects: The 2002 Revision

52) www.census.gov/ipc/www/iddnew.html US Census Bureau (on line) International Data Base, nited States Bureau of the Census. Washington DC. This is a computerized source of dermograpic and socio-econmic statistics for 227 countries and areas of the world from 1950 to the present, and projected demographic data to 2050, freely available on the World Wide Web.

53) www.populationaction.org Home of Population Action International, an organization dedicated to advancing policies and programmes that show population growth in order to improve quality of life for all people.

\section{ENDNOTES}

${ }^{1}$ Defining old age is difficult, as there is no universally accepted age that is considered old among or within societies. Old age is often explained in different ways. In developed countries, it tends to be linked to the age of eligibility for retirement and old-age social programs, which is 60 or 65 years; but this concept of retirement has little relevance for most Sub-Saharan African countries, where only two countries, South Africa and Botswana have old-age social programmes. Moreover, biologists are not in agreement about the existence of an inherent biological cause for aging; and generally speaking, different societies around the world regard old age as occurring anywhere from the mid-40s to the $70 \mathrm{~s}$. In this paper, older people are defined to be those aged 50 and older and/or 60 and older.

${ }^{2}$ Ageing is taken as the ultimate end. Old age consists of ages nearing or surpassing the average life span of human being, and thus the end of the human life cycle - various terms and euphemisms are used to refer to old people in different societies including seniors (American usage), Senior Citizens (British usage), or the elderly.

${ }^{3}$ For the purpose of this paper, Sub-Saharan Africa includes 50 (out of the usual 54) countries as commonly used in the UN Reports and the US Census. Consequently, this paper focuses on 42 countries that had total population of at least 1 million in 2006 . The current Africa total population is estimated at 800 million. The number of Africans aged 60 or older is estimated to be $35-40$ million. 
The countries not included in the UN Reports and the US Census Statistics are Cape Verde, Comoros, Djibouti, Equatorial Guinea, Mayotte, Saint Helena, Sao Tome and Principe, and Seychelles. Mauritius, although has a population of over 1 million, is also excluded from the US Census statistics because it has demographic outliers.

${ }^{4}$ A United Nation's Report was recently launched in Nairobi in which the British High Commissioner to Kenya observed that old age is now a major threat to development in the developing countries. Consequently, the UN has established a UN programme whose aim is to assess and address the old age problems overseen by the World Health Organization (WHO). The UN also designated 1999 as the International Year of older Persons.

5 The "developed" and "developing" country categories used in this paper correspond to the "more developed" and "less developed" classification employed by the United Nations. Developed countries comprise all nations in Europe (including nations such as Belarus, Estonia, Latvia, Lithunuania, Moldovia, Russia and Ukraine that were formerly part of the Soviet Union) and Northern America, plus Japan, Australia, and New Zealand. The remaining nations of the world are classified as developing countries.

${ }^{6}$ A Report on an experts Meeting to prepare a draft OAU Policy Framework and Plan of Action on Aging (HAI 2000) noted that in many countries in Africa, the trend towards an ageing society has not yet attracted the attention that it deserves from policy makers and planners. At the moment, few African countries have developed policy on old age. For further details on old age policy in SubSaharan Africa, see for instance, Apt 1999; Omondi (forthcoming).

${ }^{7}$ As people age, there is often a general physical decline, and people become less active. Old age can cause, amongst other things: (1) wrinkles and liver spots on the skin, (2) change of hair colour usually from black to gray or white, (3) hair loss, (4) lessened hearing, (5) worse eyesight, (6) slower reaction times and agility, (7) reduced ability to think clearly, (8) difficulty recalling memories, (9) lessening or cessation of sex, sometimes because of physical symptoms such as erectile dysfunction in men, but often simply a decline in libido, and (10) greater susceptibility to bone diseases such as osteoarthritis.

${ }^{8} \mathrm{HIV}$ : (Human Immune Deficiency Virus) is the virus, which leads to AIDS (Acquired Immuno-deficiency Syndrome), while AIDS Refers to Acquired Immune deficiency Syndrome. It is caused by a virus (HIV) which attacks the body's defence mechanisms, weakening it thus exposing one to various infections such as T.B., persistent diarrhea and vomiting, skin infections, pneumonia, and so on. The progression of these infections often leads to death of the victims.

${ }^{9} \mathrm{~A}$ recent study by Help-Age found that HIV is spreading fast among the older people. It was found that older people, previously assumed not to be at risk to HIV/Aids scourge, are increasingly being affected due to various reasons including introduction of sex performance-enhancing drugs such as viagra, increasing divorce rates, continued polygamy, marriage involving young women, twilight girls turning to older people who have more money, and other factors.

10. State institutions to aid the elderly have existed in varying degrees since the time of the ancient Roman Empire. In 1601, England enacted the Poor law which recognized the state's responsibility to the aged, although programs were carried out by local church parishes. An amendment to this law in 1834 instituted workhouses for the poor and aged, and in 1925 England introduced social insurance for the aged regulated by statistical evaluations. In 1940 programs for the aged came under England's welfare state system. In Germany, the 1880s Otto von Bismarck introduced old-age pensions whose model was followed by most other western European countries. Today more than 100 nations have some form of social security program for the aged. In Africa, however, it is only South Africa and Namibia; although Kenya is currently toying with a pilot programme to provide the elderly with Kshs 1,500 per month in selected counties. The United States was one of the last countries to institute old age social programmes. Not until the Social Security Act of 1935 was formulated in the USA to relieve hardships caused by the Great Depression were the elderly granted oldage pensions. For the most part, these state programs, while alleviating some burdens of aging, still do not bring older people to a level of income comparable to that of younger people.

${ }^{11}$ The conventional approach to caring for the older people and orphaned children has been through institutionalization - creating homes for the elderly and children, most of them usually in urban areas. This is the opposite of the African traditional approach of caring for the elderly which were aimed at accommodating them within their own homes, in a closely knit integrated society. The conventional approach, although necessary and in some cases, respond to the very real needs, particularly for physical care, they often take the clients away from their relatives, and in some cases, have enormous impacts of the people being cared for. Many studies indicate that none of these institutions has proven to be an acceptable substitute for the family in providing emotional, psychological and social support. In some cases, they are like having the ailing grandparents living in prison-like circumstances. The view of this paper is that older people who are still active should be integrated into their societies and homes left only for the frail and the very sick ones.

${ }^{12}$. Older people are rarely considered in the recovery or credit packages. Older women, in particular suffer a double disadvantage as they often emerge from the crisis with greater responsibilities and fewer resources than men. Older women's place in the informal economic sector leaves them with few marketable skills and no retirement compensation. Older widows are often among the most marginalized in cultures where inheritance codes dispossess them on their husband's death. Many older women care for orphans, either their own grandchildren or others (Omondi Forthcoming 
${ }^{13}$ After the immediate crisis comes the task of rebuilding homes, livelihoods, and communities and dealing with grief and loss. HelpAge International's research shows that, even in the initial emergency, older people's main concern is with the longer-term threat to their livelihoods and homes. This is generally mismatched with relief agencies' focus on short-term welfare. Old people have limited regenerative abilities and are more prone to disease, syndromes, and sickness than other adults. The medical study of the aging process is gerontology, and the study of diseases that afflict the elderly is geriatrics. In most parts of the world, women live, on average, longer than men. Not only are older men and women's needs in emergencies frequently overlooked but the gendered nature of old age and the cumulative impacts of a life of gender-based experiences is rarely acknowledged even by gender and development practitioners, let alone mainstream humanitarian relief organisations.

14. For current infection rates for Africa and Kenya and other countries, contact the Web site for United Nations AIDS Division (UNAIDS): www.unaids.org. For further reading on more general macroeconomic impacts of AIDS on Kenyan society, see Ogot (2008) and World Bank (2005); Kamaara (2008); and Kafu (2007).

15. A recent study by Help found that HIV is spreading fast among the elderly are also at risk of contracting HIV, as yet at the moment, most campaigns against HIV/Aids pandemic target the young people, who are considered sexually active. There are many factors contributing to older people being infected by HIV include the use of Viagra that makes many sexually active, marrying younger ladies, young girls being attracted to older men with many, high rate of divorce and/or separation, amongst many other factors.

17. The International Strategy for Action on Ageing that was adopted at the Second World Assembly on Ageing in April 2002, was a prime opportunity to ensure the rights of older men and women are respected in humanitarian relief efforts and that the specific gender needs of older women and men are acknowledged and acted upon. The African Union Policy Framework and Plan of Action on old age, developed in conjunction with HelpAge International Africa Regional Development Centre, received its final seal of approval at the meeting of the AU Heads of State and Government in July 2002. Copies available from the (AU) or HAI. 